\title{
Pengaruh limbah baglog dan sungkup plastik terhadap pertumbuhan dan hasil cabai merah keriting
}

\author{
Effect spent mushroom substrate and rain shelter to growth and productivity of Capsicum annum $\mathrm{L}$. \\ Fahri Ali $^{1 *}$, Raida Kartina ${ }^{1}$, Reny Mita Sari ${ }^{1}$, dan Rianida Taisa ${ }^{2}$ \\ ${ }^{1}$ Program Studi Teknologi Produksi Tanaman Hortikultura, Politeknik Negeri Lampung \\ ${ }^{2}$ Program Studi Hortikultura, Politeknik Negeri Lampung \\ *Email korespondensi: fahrialihorti@polinela.ac.id
}

Diterima: 31 Januari 2021 / Disetujui: 18 Maret 2021

\begin{abstract}
The productivity of great chili in Lampung decrease amount 24.7\% in 2018. The productivity in 2017 was 88.23 quintal/ha and decrease to 66.41 quintal/ha in 2018. It caused by the low contain of C-organic in soil and the high rate of shedding on chili's flower. The spent mushroom substrate is potential material that can be used to repair the soil quality because of its porosity, so the spent mushroom substrate will be easy to be absorbed, keep and drain much the water, also it contain nutrition for plants. The curve rain shelter can be used to reduce the fall of chili's flower and it is also can hold the drop of rain directly to the plants and optimizing the use of pesticides and foliar fertilizer. The aim of this research is to study the effect of application of spent mushroom substrate and rain shelter to growth and productivity of chilies, and study the interaction effect between it. This research was implemented in Horticulture practical land of Politeknik Negeri Lampung, Bandar Lampung from July to October 2020. This research was conducted using randomized block design in two factorials, with 3 times repeated. The first factor consist of 3 treatments of the dose of spent mushroom substrate; 0 (control), 20 tonnes /ha, and 40 tonnes tha. The second factor consist of 2 treatments of shedding; without rain shelter (control) and with rain shelter. The data are analysed with F-test then proceed with Tukey HSD at 5\% level. The results showed th application 40 tonnes tha of spent mushroom substrate increase the plants height, the number of branches, and the weight of its fruit per plot. The 40 tonnes /ha dose application of spent mushroom substrate showed the best effect to the number of branches and weight of the fruit per plot. The application of rain shelter has no effect to growth and productivity of chili, and also no interaction between application of spent mushroom substrate and rain shelter to all observation variable.
\end{abstract}

Keywords: chili, rain shelter, spent mushroom substrate.

\begin{abstract}
ABSTRAK
Produktivitas cabai besar di Provinsi Lampung menurun pada tahun 2018 sebesar 24,7\%, dari 88,23 kuintal/ha pada tahun 2017 menurun menjadi 66,41 kuintal/ha pada tahun 2018. Hal tersebut salah satunya disebabkan karena kandungan Corganik tanah yang rendah dan tingginya kerontokan bunga cabai. Limbah baglog jamur merupakan bahan yang potensial digunakan sebagai bahan pembenah tanah karena memiliki sifat porous, sehingga mudah menyerap dan menyimpan air, serta mengalirkan air dalam jumlah yang banyak dan mengandung nutrisi untuk tanaman. Untuk mengurangi serangan kerontokan bunga cabai dapat digunakan sungkup plastik berbentuk melengkung yang dapat menahan jatuhnya air hujan secara langsung pada tanaman dan mengoptimalkan penggunaan pestisida dan pupuk daun. Penelitian ini dilaksanakan dengan tujuan mengkaji pengaruh pemberian limbah baglog dan sungkup plastik terhadap pertumbuhan dan hasil cabai, dan mengkaji pengaruh interaksi antara pemberian limbah baglog dan sungkup plastik terhadap pertumbuhan dan hasil cabai. Penelitian ini telah dilaksanakan di lahan praktik hortikultura Politeknik Negeri Lampung, Bandar Lampung. Waktu penelitian dimulai bulan Juli sampai Oktober 2020. Penelitian ini merupakan percobaan faktorial $3 \times 2$ dengan menggunakan Rancangan Acak Kelompok (RAK) dengan tiga ulangan. Faktor pertama yang dicoba yaitu dosis limbah baglog yang terdiri dari 0 (kontrol), 20 ton/ha dan 40 ton/ha. Faktor kedua adalah penggunaan sungkup plastik yang terdiri dari tanpa sungkup (kontrol) dan pemberian sungkup plastik. Data yang diperoleh dianalisis dengan menggunakan uji $F$, jika nyata dilanjutkan dengan Uji BNJ pada taraf 5\%. Hasil penelitian menunjukkan pemberian limbah baglog jamur meningkatkan tinggi tanaman, jumlah cabang dan bobot buah cabai per petak. Dosis limbah baglog 40 ton/ha memberikan hasil terbaik pada jumlah cabang dan bobot buah cabai per petak. Penggunaan sungkup plastik tidak berpengaruh terhadap pertumbuhan dan hasil cabai, dan tidak terjadi interaksi antara pemberian limbah baglog jamur dengan penggunaan sungkup plastik terhadap semua variabel pengamatan.
\end{abstract}

Kata kunci: cabai, limbah baglog, sungkup plastik. 


\section{PENDAHULUAN}

Produktivitas cabai besar di Provinsi Lampung menurun pada tahun 2018 sebesar $24,7 \%$, dari 88,23 kuintal/ha pada tahun 2017 menurun menjadi 66,41 kuintal/ha pada tahun 2018 (Badan Pusat Statistik Provinsi Lampung, 2018). Hal tersebut salah satunya disebabkan karena kandungan C-organik tanah yang rendah yaitu $<2$ (Hafif et al., 2016; Nurida et al., 2017). C-organik tanah merupakan bagian penting dari bahan organik tanah yang menentukan kesuburan dan produktivitas tanah karena dapat memperbaiki sifat fisik, kimia dan biologi tanah.

Salah satu cara untuk meningkatkan kandungan Corganik tanah adalah dengan penggunaan bahan-bahan yang tersedia di lokasi setempat atau bersifat in situ. Sumber bahan organik yang potensial di Provinsi Lampung adalah limbah baglog jamur. Provinsi Lampung merupakan salah satu sentra produksi jamur di Indonesia. Tahun 2018 produksi jamur di Provinsi Lampung sebesar 280,971 ton (Badan Pusat Statistik, 2018). Tingginya produksi jamur menjadikan limbah baglog juga mengalami peningkatan. Semakin menumpuknya limbah baglog akan menimbulkan masalah bagi lingkungan seperti bau busuk dan masalah lain yang terkait dengan polusi udara.

Baglog jamur merupakan media tanam jamur berbahan utama serbuk gergaji. Limbah baglog jamur dihasilkan dari media tanam jamur yang sudah tidak produktif. Menurut Bellapama et al. (2015) limbah baglog jamur tiram mengandung kadar air 37, 241\%, nitrogen sebesar $0,931 \%$, fosfor sebesar $2,070 \%$, kalium $8,515 \%$, dan $\mathrm{C} / \mathrm{N}$ rasio sebesar 37,199. Limbah baglog jamur potensial dimanfaatkan sebagai bahan pembenah tanah karena dapat

\section{BAHAN DAN METODE}

Penelitian ini merupakan percobaan faktorial $3 \times 2$ dengan menggunakan Rancangan Acak Kelompok (RAK) dengan tiga ulangan. Faktor pertama yang dicoba yaitu dosis limbah baglog yang terdiri dari 0 (kontrol), 20 ton/ha dan 40 ton/ha. Faktor kedua adalah penggunaan sungkup plastik yang terdiri dari tanpa sungkup (kontrol) dan pemberian sungkup plastik. Variabel yang diamati yaitu kandungan limbah baglog jamur, tinggi tanaman, jumlah cabang dan bobot buah cabai per petak. Data yang diperoleh dianalisis dengan menggunakan uji $\mathrm{F}$, jika nyata dilanjutkan dengan Uji BNJ pada taraf 5\%.

Limbah baglog yang digunakan dalam penelitian ini tidak dikomposkan terlebih dahulu, karena sudah memenuhi standar SNI Spesifikasi kompos dari sampah organik domestik. Limbah baglog yang digunakan adalah limbah baglog terkontaminasi. Limbah baglog terkontaminasi memiliki kandungan hara yang lebih tinggi dibandingkan dengan limbah baglog yang sudah habis masa produksinya (Sulaeman, 2011). Menurut hasil identifikasi Aliah (2014), penyebab kontaminasi pada media tumbuh jamur tiram yaitu memperbaiki kapasitas penyangga tanah dan menjaga kelembaban tanah.

Penurunan produksi cabai di Provinsi Lampung juga disebabkan karena serangan organisme pengganggu tanaman (OPT). Penyakit yang banyak menyerang pertanaman cabai salah satunya adalah antraknosa (patek) yang disebabkan oleh patogen Colletotrichum capsici. Penyakit antraknosa merupakan masalah utama bagi para petani cabai karena dapat menurunkan produksi antara 20-90\% (Balai Penelitian dan Pengembangan Pertanian, 2016). Herwidyarti et al. (2013) melaporkan keparahan penyakit antraknosa di lahan cabai Bandar Lampung mencapai 44\%. Sementara itu, penyakit antraknosa yang menyerang tanaman cabai di Provinsi Lampung tahun 2010 mencapai 511 ha dengan kategori serangan ringan sampai berat (UPTD BPTPH Provinsi Lampung, 2010).

Penyakit antraknosa distimulir oleh kondisi lembab dan suhu relatif tinggi, oleh karena itu perlu pemberian sungkup plastik (rain shelter) berbentuk terowongan untuk mengurangi jumlah air hujan yang jatuh ke pertanaman cabai sehingga kelembaban di sekitar tanaman tetap terjaga dan menghambat perkembangan jamur Colletotrichum capsici. Penggunaan sungkup plastik juga dapat mengoptimalkan penggunaan pestisida, pupuk daun, menjaga lengas tanah dan meningkatkan suhu di sekitar tanaman pada malam hari.

Kerontokan bunga cabai yang tinggi juga saat ini banyak dialami petani cabai di Lampung Utara (Wirata, 2020). Sungkup plastik selain dapat mengurangi serangan organisme pengganggu tanaman (OPT) juga dapat melindungi tanaman dari terpaan air hujan secara langsung, sehingga bunga tidak mudah rontok.

jamur Rhizopus sp., Aspergillus fumigatus, Aspergillus niger dan Mucor sp. Jamur-jamur tersebut berperan mendegradasi bahan organik dan tidak menyebabkan penyakit pada tanaman. Aplikasi limbah baglog jamur diberikan pada lubang tanam dengan dosis 20 ton/ha $(0,9 \mathrm{~kg} / \mathrm{lubang}$ tanam $)$ dan 40 ton/ha $(1,8 \mathrm{~kg} /$ lubang tanam $)$. Sungkup dibuat berbentuk melengkung dengan rangka dari besi dan bambu dengan ukuran panjang $6 \mathrm{~m}$, lebar 1,2 $\mathrm{m}$ dan tinggi puncak 2 m. Plastik yang digunakan adalah plastik UV dengan ketebalan 0,13 mm. Sungkup plastik diaplikasikan pada saat berbunga. Bentuk sungkup plastik yang paling baik adalah bentuk melengkung yang dipasang pada saat berbunga (Setiawati et al., 2018).

\section{HASIL DAN PEMBAHASAN}

Limbah baglog jamur yang digunakan dalam penelitian mengandung $\mathrm{N}, \mathrm{P}$, dan $\mathrm{K}$ total masing-masing sebesar 0,$76 ; 0,77$ dan $0,46 \%$. Limbah baglog jamur juga mengandung C-Organik 10,63\%, dengan nisbah C/N 13,95, pH $\quad \mathrm{H}_{2} \mathrm{O} \quad 8,79$ dan kadar air 73,74\%. Hasil analisis kandungan limbah baglog jamur disajikan pada Tabel 1 . 
Tabel 1. Kandungan limbah baglog jamur

\begin{tabular}{clcccc}
\hline No. & Parameter & Satuan & Hasil uji & SNI 19-7030-2004 & Keterangan \\
\hline 1 & N Total & $\%$ & 0,76 & 0,40 & Minimum \\
2 & P2O5 Total & $\%$ & 0,77 & 0,10 & Minimum \\
3 & K2O Total & $\%$ & 0,46 & 0,20 & Minimum \\
4 & C-Organik & $\%$ & 10,63 & $9,80-32$ & - \\
5 & pH H2O & & 8,79 & $6,8-7,49$ & - \\
6 & Kadar Air & $\%$ & 73,74 & 50,00 & Maksimum \\
7 & C/N Rasio & & 13,95 & $10-20$ & - \\
\hline
\end{tabular}

Keterangan: Contoh limbah baglog jamur dianalisis di Laboratorium Analisis Politeknik Negeri Lampung, Bandar Lampung.

Tabel 2. Pengaruh limbah baglog jamur terhadap tinggi tanaman, jumlah cabang dan bobot buah cabai per petak

\begin{tabular}{cccc}
\hline Perlakuan dosis limbah baglog jamur & \multicolumn{3}{c}{ Variabel yang diamati } \\
\cline { 2 - 4 } (ton/ha) & Tinggi tanaman $(\mathrm{cm})$ & Jumlah cabang & Bobot buah per petak $(\mathrm{g})$ \\
\hline 0 & $25,83 \mathrm{a}$ & $19,67 \mathrm{a}$ & $3.764,2 \mathrm{a}$ \\
20 & $28,00 \mathrm{~b}$ & $23,83 \mathrm{ab}$ & $4.198,0 \mathrm{ab}$ \\
40 & $27,17 \mathrm{ab}$ & $25,50 \mathrm{~b}$ & $4.373,8 \mathrm{~b}$ \\
\hline
\end{tabular}

Keterangan: Angka yang diikuti oleh huruf yang sama pada kolom yang sama menunjukkan tidak berbeda nyata dengan uji BNJ pada 5\%.

Hasil analisis di atas menunjukkan komposisi kadar hara ( $\mathrm{N}, \mathrm{P}$, dan $\mathrm{K})$, C-Organik dan nisbah $\mathrm{C} / \mathrm{N}$ limbah baglog jamur yang sudah memenuhi standar SNI Spesifikasi kompos dari sampah organik domestik. Penggunaan limbah baglog jamur selain bertujuan meningkatkan C-Organik tanah, juga untuk meningkatkan ketersediaan hara terutama $\mathrm{N}$, P, dan K. Kemampuan tanah dalam memegang air maupun hara diharapkan akan meningkat, demikian juga dengan serapan hara tersebut oleh tanaman.

Hasil penelitian menunjukkan pemberian limbah baglog jamur dapat meningkatkan pertumbuhan dan hasil cabai. Hal tersebut dapat dilihat dari tinggi tanaman, jumlah cabang dan bobot buah cabai per petak (Tabel 2).

Peningkatan tinggi tanaman, jumlah cabang dan bobot buah cabai disebabkan karena limbah baglog berfungsi sebagai pembenah tanah yang dapat memperpaiki sifat fisik tanah. Menurut Sulaeman (2011), limbah baglog jamur tiram putih dapat meningkatkan kemampuan tanah menahan air. Dengan ditambahkannya kompos ke dalam tanah, maka kemampuan memegang air tanah dapat ditingkatkan, sehingga tanah tidak cepat meloloskan air baik sebagai air drainase maupun air perkolasi. Selain itu, air juga tidak mudah terevaporasi karena terlindungi dan atau terikat oleh bahan kompos. Dengan demikian kadar air dalam tanah dapat dipertahankan pada kondisi yang optimal dalam jangka yang lebih lama. Kapasitas retensi air dan ketersediaannya bagi tanaman meningkat demikian pula stabilitas struktur (Gobat et al., 1998 dalam Suhartini, 2003).

Pemberian limbah baglog juga dapat meningkatkan $\mathrm{pH}$ tanah (Sulaeman, 2011). Peningkatan $\mathrm{pH}$ tanah ini diduga disebabkan adanya efek asam-asam organik dalam mengikat ion Al dan meningkatkan KTK tanah; semakin besar takaran kompos yang diberikan pada tanah maka berpeluang semakin besar asam organik yang akan disumbangkan kepada tanah. Asam-asam organik tersebut dapat mengkhelat ion $\mathrm{Al}$ sehingga menghambat hidrolisis $\mathrm{Al}$ yang akan menghasilkan ion $\mathrm{H}^{+}$, akibatnya $\mathrm{pH}$ tanah meningkat. Selain itu, peningkatan kandungan bahan organik tanah juga dapat meningkatkan KTK tanah sehingga ion $\mathrm{H}^{+}$dalam larutan tanah dapat berkurang (Anwar et al., 2006).

Dengan meningkatnya kemampuan tanah menahan air dan meningkatnya $\mathrm{pH}$ tanah pada pemberian limbah baglog menjadikan tingginya penyerapan air dan unsur hara tanaman. Air dan unsur hara merupakan senyawa utama yang dibutuhkan dalam proses fotosintesis, sehingga laju fotosintesis tanaman meningkat. Tinggi tanaman, jumlah cabang dan bobot buah adalah efek dari akumulasi fotosintat yang ditranslokasikan oleh daun ke daerah batang dan buah. Batang dan buah sendiri berperan sebagai lubuk, sehingga tinggi tanaman, jumlah cabang dan bobot buah dapat digunakan sebagai indikator kemampuan sumber dalam menghasilkan fotosintat.

Peningkatan bobot buah cabai per petak akibat penambahan limbah baglog jamur menunjukkan pola linier sampai dengan dosis sebesar 40 ton/ha (Gambar 1). Peningkatan dosis limbah baglog jamur sampai dengan 40 ton/ha selalu diikuti oleh peningkatan bobot buah cabai per petak. Hal ini sesuai dengan hasil penelitian Fikri et al. (2015), peningkatan hasil panen tanaman kangkung akibat penambahan kompos media tanam jamur tiram menunjukkan pola linier sampai dengan takaran sebesar 40 ton/ha, kenaikan takaran kompos sampai dengan 40 ton/ha selalu diikuti oleh peningkatan hasil panen kangkung darat. Selain itu, Kochakinezhad et al. (2012) juga melaporkan pemberian limbah baglog jamur tiram dengan dosis 20 ton/ha meningkatkan hasil tomat varietas Redstone dan Chief. Penggunaan sungkup plastik tidak berpengaruh terhadap tinggi tanaman, jumlah cabang dan bobot buah cabai per petak (Tabel 3).

Penggunaan sungkup plastik yang tidak berpengaruh terhadap tinggi tanaman, jumlah cabang dan bobot buah per petak disebabkan karena curah hujan selama pertumbuhan tanaman yaitu bulan Agustus dan September 2020 masing- 


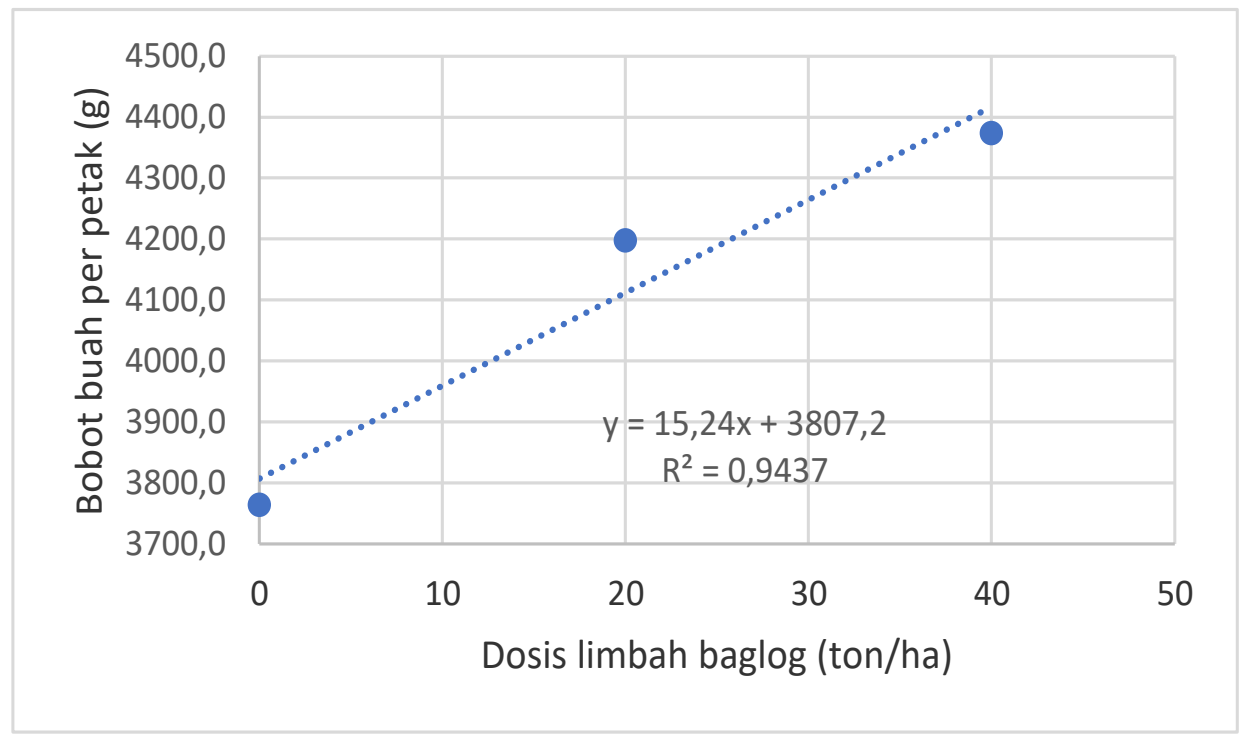

Gambar 1. Regresi bobot buah cabai per petak dan dosis limbah baglog jamur

Tabel 3. Pengaruh sungkup plastik terhadap tinggi tanaman, jumlah cabang dan bobot buah cabai per petak

\begin{tabular}{cccc}
\hline Perlakuan sungkup plastik & \multicolumn{3}{c}{ Variabel yang diamati } \\
\cline { 2 - 4 } & Tinggi tanaman $(\mathrm{cm})$ & Jumlah cabang & Bobot buah per petak $(\mathrm{g})$ \\
\hline Tanpa sungkup & $26,78 \mathrm{a}$ & $22,22 \mathrm{a}$ & $4.087,3 \mathrm{a}$ \\
Sungkup plastik & $27,22 \mathrm{a}$ & $23,78 \mathrm{a}$ & $4.136,7 \mathrm{a}$ \\
\hline Keterangan: & angka & . & \\
\hline
\end{tabular}

Keterangan: Angka yang diikuti oleh huruf yang sama pada kolom yang sama menunjukkan tidak berbeda nyata dengan uji BNJ pada 5\%.

masing 125,7 mm (sedang) dan 61,5 (rendah) dengan jumlah hari hujan yang sama yaitu 9 hari (Stasiun Meteorologi Pertanian Khusus Politeknik Negeri Lampung, 2020). Kondisi curah hujan tersebut menjadikan tidak ada perbedaan iklim mikro antara pertanaman cabai yang disungkup dengan yang tidak disungkup karena lamanya penyinaran matahari optimal.

Tujuan penggunaan sungkup plastik adalah untuk mengurangi tingginya bunga rontok akibat derasnya terpaan air hujan dan mengoptimalkan penggunaan pestisida dan pupuk daun. Curah hujan yang rendah selama penelitian tidak mempengaruhi jumlah bunga rontok dan pencucian pestisida dan pupuk daun oleh air hujan. Hal tersebut dapat dilihat dari bobot buah per petak yang tidak berbeda nyata.

\section{KESIMPULAN}

Pemberian limbah baglog jamur meningkatkan tinggi tanaman, jumlah cabang dan bobot buah cabai per petak. Dosis limbah baglog 40 ton/ha memberikan hasil terbaik pada jumlah cabang dan bobot buah cabai per petak. Penggunaan sungkup plastik tidak berpengaruh terhadap pertumbuhan dan hasil cabai. Tidak terjadi interaksi antara pemberian limbah baglog jamur dengan penggunaan sungkup plastik terhadap semua variabel pengamatan.

\section{UCAPAN TERIMA KASIH}

Ucapan terima kasih disampaikan kepada Politeknik Negeri Lampung yang telah membantu pendanaan dalam penelitian ini melalui DIPA Dosen Politeknik Negeri Lampung Tahun Anggaran 2020.

\section{DAFTAR PUSTAKA}

Aliah, M. (2014). Pengendalian Pertumbuhan Jamur Kontaminan pada Media Budidaya Jamur Tiram (Pleurotus ostreatus (Jacq. ex Fr. Kummer) dengan Ekstrak Etanolik Lengkuas (Alpinia Galanga L.) [Skripsi]. Yogjakarta: Universitas Gadjah Mada.

Anwar, K., S. Sabiham, B. Sumawinata, A. Sapei \& T. Alihamsyah. (2006). Effect of Straw Compost on Soil Quality, Soluble $\mathrm{Fe}^{2+}$ and SO42- and Rice Production of Sulfid Acid Soil (in Indonesian). Journal of Soil and Climate, (24), 29-39.

Badan Pusat Statistik. (2018). Produksi Tanaman Sayuran Jamur Provinsi Lampung https://bps.go.id/site/resultTab [22 Maret 2020].

Badan Pusat Statistik Provinsi Lampung. (2018). Produksi Tanaman Sayuran dan Buah-buahan Provinsi Lampung 2018. BPS Provinsi Lampung, Lampung. 
Badan Standardisasi Nasional. (2004). SNI 19-7030-2004 tentang Spesifikasi Kompos dari Sampah Organik Domestik.

Balai Penelitian dan Pengembangan Pertanian. (2016). Pengendalian antraknosa pada tanaman cabai http://www.litbang.pertanian.go.id/ berita/one/2630/ [22 Maret 2020].

Bellapama, I.A., Hendarto, K. \& Widyastuti, R.A.D. (2015). Pengaruh Pemupukan Organik Limbah Baglog Jamur dan Pemupukan Takaran NPK terhadap Pertumbuhan dan Produksi Pakchoy (Brassica chinensis L.). J. Agrotek Tropika, 3(3), 327-331.

Fikri, M.S., Indradewa D. \& Putra E.T.S. (2015). Pengaruh Pemberian Limbah Media Tanam Jamur Pada Pertumbuhan dan Hasil Kangkung Darat (Ipomoea reptans Poir.), Vegetalika, 4(2), 79-89.

Hafif, B. (2016). Optimasi Potensi Lahan Kering untuk Pencapaian Target Peningkatan Produksi Padi Satu Juta Ton di Provinsi Lampung. Jurnal Litbang Pertanian, 35(2), 81-88.

Herwidyarti, K.H., Ratih, S. \& Sembodo, D.R.J. (2013). Keparahan Penyakit Antraknosa pada Cabai (Capsicum annum L.) dan Berbagai Jenis Gulma. $J$. Agrotek Tropika, 1(1), 102-106.

Kochakinezhad, H., Peyvast, Gh., Kashi, A.K., Olfati, J.A. \& Asadii, A. (2012). A Comparison of Organic and Chemical Fertilizers for Tomato Production. Journal of Organic System, 7(2), 14-25.
Nurida, N.L., Sutono \& Muchtar. (2017). Pemanfaatan Biochar Kulit Buah Kakao dan Sekam Padi untuk Meningkatkan Produktivitas Padi Sawah di Ultisol Lampung. Jurnal Pengkajian dan Pengembangan Teknologi Pertanian, 20(1), 69-80.

Setiawati, W., Hasyim A. \& Hudayya A. (2018). Penggunaan Rain Shelter dan Biopestisida Atecu Pada Budidaya Cabai di Luar Musim untuk Mengurangi Kehilangan Hasil dan Serangan OPT, Jurnal Hortikultura, 28(2), 239-250.

Stasiun Meteorologi Khusus Pertanian Politeknik Negeri Lampung. (2020). Curah Hujan Harian Tahun 2020. Politeknik Negeri Lampung, Bandar Lampung.

Suhartini. (2003). Pengomposan Limbah Organik Pertanian Untuk Menghasilkan Pupuk Organik yang Sehat dan Ramah Lingkungan [Makalah]. Surakarta: Universitas Sebelas Maret.

Sulaeman, D. (2011). Efek Kompos Limbah Baglog Jamur Tiram Putih (Pleurotus ostreatus Jacquin) terhadap Sifat Fisik Tanah serta Pertumbuhan Bibit Markisa Kuning (Passiflora edulis var. Flavicarpa Degner) [Skripsi]. Bogor: Institut Pertanian Bogor.

UPTD BPTPH Provinsi Lampung. (2010). Laporan Tahunan 2010. Balai Proteksi Tanaman Pangan dan Hortikultura Provinsi Lampung.

Wirata, I.M. (2020). Petani cabai diimbau gunakan sungkup https://www.lampost.co/berita-petani-cabai-diimbaugunakan-sungkup.html [22 Maret 2020]. 